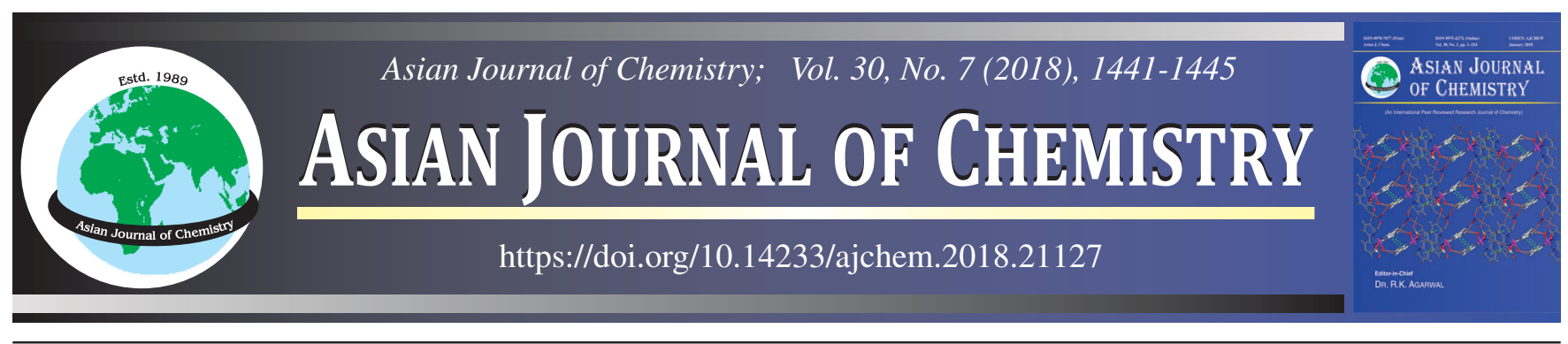

\title{
A Novel One-Pot Synthesis, Characterization, DNA Binding and Cleavage Studies on bis(Phenylhydrazoneglyoxylato)diaqua Metal(II) Complexes
}

\section{R. PRADEEP and B.N. SivasAnKar*}

Department of Chemistry, Government Arts College, Udhagamandalam, The Nilgiris-643 002, India

*Corresponding author: E-mail: sivabickol@yahoo.com

Phenylhydrazoneglyoxylic acid, $\mathrm{C}_{6} \mathrm{H}_{5} \mathrm{NHN}=\mathrm{CHCOOH}$, formed in situ by the aqueous condensation between phenyl hydrazine and glyoxylic acid, in the presence of metal ions such as $\mathrm{Mn}(\mathrm{II}), \mathrm{Co}(\mathrm{II}), \mathrm{Ni}(\mathrm{II}), \mathrm{Cu}(\mathrm{II}), \mathrm{Zn}$ (II) and $\mathrm{Cd}(\mathrm{II})$ yielded water insoluble bis(phenylhydrazoneglyoxylato)diaqua metal(II) complexes. These complexes were characterized by analytical, spectral (UV-visible, IR and NMR) and thermal techniques. Infrared, NMR and X-ray powder diffraction patterns reveal the formation and isomorphic nature of $\left[\mathrm{M}\left(\mathrm{OOCCH}=\mathrm{NNHC}_{6} \mathrm{H}_{5}\right)_{2}\left(\mathrm{H}_{2} \mathrm{O}\right)_{2}\right]$ complexes. Thermal degradation studies show multi-step degradation behaviour and the final weight losses are in accordance with the formation of respective metal oxides as end residues. Octahedral geometry around the metal ion has been proposed on the basis of spectral and thermal studies. The interaction of the complexes with calf thymus-DNA (ctDNA) has been explored by absorption titration method which revealed that the compounds could interact with $c t$ DNA through electrostatic interaction. The gel electrophoresis assay demonstrated the zinc complex exhibit good cleavage efficiency, which is concentration dependent.

Keywords: Phenylhydrazoneglyoxylate, Aqueous condensation, Isomorphism, Octahedral, DNA binding and Cleavage.

\section{INTRODUCTION}

Condensation between aldehydes and amines or hydrazine derivatives conducted in organic medium has been exhaustively investigated. The hydrazones formed during these condensations have been utilized in the synthesis of variety of biological active coordination compounds. However, the aqueous condensation is not common with amines/hydrazines and aldehydes. Glyoxylic acid (OHCCOOH) is a monocarboxylic acid containing aldehyde group and its reactions with ammonia and hydrazine are quite interesting. Carboxylic acids and substituted carboxylic acids react with hydrazine hydrate in aqueous medium yield hydrazinium carboxylates salts [1-6]. In the presence of metal ions, aqueous mixture of carboxylic acids and hydrazine hydrate always yielded hydrazine/hydrazinium metal carboxylates $[7,8]$. The aldehyde group in glyoxylic acid is not expected to undergo condensation with amino derivatives in aqueous medium though in organic solvents the formations of hydrazones are very common. In the present investigation, novel hydrated phenyl hydrazoneglyoxylate complexes have been synthesized by the aqueous condensation between phenyl hydrazine and glyoxylic acid in the presence of metal(II) ions. In spite of information available on hydrazine based metal carboxylates, few reports are available on phenyl hydrazinium based metal complexes [9-12]. In view of the above facts, the present article embodies the spectral and thermal studies on the newly synthesized bis(phenylhydrazone glyoxylato)diaqua metal(II) complexes. In addition, the interaction behaviour with $c t$ DNA and the cleavage efficiency have been explored.

\section{EXPERIMENTAL}

All the chemicals used were of AnalaR grade and phenyl hydrazine was distilled before use. Double distilled water was used for the preparation of the complexes. Calf thymus DNA (ctDNA) was purchased from Merck and stored at $4{ }^{\circ} \mathrm{C}$. The $\mathrm{C}, \mathrm{H}$ and $\mathrm{N}$ analyses were carried out using a Perkin-Elmer model $1240 \mathrm{CHN}$ analyzer. The metal contents in the complexes were determined by EDTA complexometric titrations after completely decomposing a known amount of complexes with concentrated nitric acid to eliminate the organic portion of the molecule [13]. The molar conductances of the complexes were measured at room temperature using Systronics-303 conductivity meter in DMSO. Room temperature magnetic moments of the complexes were determined by using a Gouy balance and $\mathrm{Hg}\left[\mathrm{Co}(\mathrm{SCN})_{4}\right]$ as the calibration standard. UVvisible absorbance spectra were recorded in the range 800$200 \mathrm{~nm}$ using Systronics double beam UV-visible spectrophotometer. The infrared absorption spectra were recorded using Perkin-Elmer 597 spectrophotometer with $\mathrm{KBr}$ pellets. 
${ }^{1} \mathrm{H}$ NMR and ${ }^{13} \mathrm{C}$ NMR spectra were recorded at $298 \mathrm{~K}$ on Bruker FT-NMR-500 spectrometer operating at $400.13 \mathrm{MHz}$ using DMSO as a solvent and tetra methyl silane as an internal standard. The simultaneous TG-DTA analyses (in $\mathrm{N}_{2}$ and air atmosphere) were undertaken on a SWI TG/DTA 6200 thermal analyzer using $5 \mathrm{mg}$ of the samples with the heating rate of 10 ${ }^{\circ} \mathrm{C}$ per min. The X-ray powder diffraction patterns were recorded on Philips PW 1050/70 using $\mathrm{Cu}-\mathrm{K}_{\alpha}$ radiation with an iron filter. The measurements were taken in the range of $2 \theta$ angle $20^{\circ}$ to $80^{\circ}$ and wavelength of $1.5406 \AA$.

\section{DNA binding and cleavage studies}

Electronic absorption titration: All the experiments involving interaction of complexes with $c t$ DNA were carried out in a buffer containing $5 \mathrm{mmol}$ of tris(hydroxy-methyl)aminomethane and $50 \mathrm{mmol}$ of $\mathrm{NaCl}$ adjusted to $\mathrm{pH} 7.2$ with hydrochloric acid. A solution of $c t$ DNA gave a ratio of UV absorbance of about 1.8-1.9 at 260 and $280 \mathrm{~nm}$, indicating that the $c t$ DNA was sufficiently free of protein [14]. The $c t$ DNA concentration per nucleotide was determined by UVspectrophotometer employing molar absorption coefficient $6600 \mathrm{M}^{-1} \mathrm{~cm}^{-1}$ at $260 \mathrm{~nm}$ [15].

Absorption titrations were carried out at room temperature for determining the binding affinity between DNA and complexes $\mathbf{2}, \mathbf{3}$ and $\mathbf{5}$. An appropriate amount of metal complexes were dissolved in a solvent mixture of $1 \%$ DMSO and $99 \%$ Tris- $\mathrm{HCl}$ buffer. Absorption titration experiments were performed with the fixed concentration of the metal complex while gradually increasing the concentration of $c t$ DNA. From the absorption titration data, the binding constant $\left(\mathrm{K}_{\mathrm{b}}\right)$ of the complexes were determined from eqn. 1, through a plot of $[\mathrm{DNA}] /\left(\varepsilon_{\mathrm{a}}-\varepsilon_{\mathrm{f}}\right) v s$. [DNA].

$$
[\mathrm{DNA}] /\left(\varepsilon_{\mathrm{a}}-\varepsilon_{\mathrm{f}}\right)=[\mathrm{DNA}] /\left(\varepsilon_{\mathrm{b}}-\varepsilon_{\mathrm{f}}\right)+1 / \mathrm{K}_{\mathrm{b}}\left(\varepsilon_{\mathrm{b}}-\varepsilon_{\mathrm{f}}\right)
$$

where, [DNA] is the concentration of DNA and $\varepsilon_{\mathrm{a}}, \varepsilon_{\mathrm{f}}$ and $\varepsilon_{\mathrm{b}}$ the apparent extinction coefficient $\left(\mathrm{A}_{\mathrm{obs}} /[\mathrm{M}]\right)$, the extinction coefficient for free metal complex (M) and the extinction coefficient for the free metal complex $(\mathrm{M})$ in the fully bound form, respectively. In plots of [DNA] $/\left(\varepsilon_{\mathrm{a}}-\varepsilon_{\mathrm{f}}\right) v s$. [DNA], $\mathrm{K}_{\mathrm{b}}$ is given by the ratio of slope to intercept [16].

Gel electrophoresis: The cleavage experiment of $c t$ DNA in $(5 \mathrm{mmol}$ Tris- $\mathrm{HCl}, 50 \mathrm{mmol} \mathrm{NaCl})$ buffer at $\mathrm{pH} 7.2$ was carried out using agarose gel electrophoresis. In this experiment, $8 \mu \mathrm{L} c t$ DNA was mixed with different concentrations of complexes (25, 50, 75 and $100 \mu \mathrm{M})$ dissolved in DMSO) to determine cleavage activity. The gel was run at $80 \mathrm{~V}$ for $2 \mathrm{~h}$ in TAE buffer and photographed under UV light.

Preparation of complexes 1-6: To an aqueous solution $(50 \mathrm{~mL})$ containing a mixture of phenyl hydrazine $(2.2 \mathrm{~mL}$, $0.02 \mathrm{~mol})$ and glyoxylic acid $(1.84 \mathrm{~g}, 0.02 \mathrm{~mol})$ an aqueous solution of respective metal nitrate hydrate $(0.01 \mathrm{~mol})$ was added with stirring. The clear solution thus obtained was allowed to stand at room temperature. The complexes precipitated from the solution after $24 \mathrm{~h}$ were filtered, washed with water and dried in air. The chemical reactions for the formation of the complexes are given in Scheme-I.
2<smiles>NNc1ccccc1</smiles>

2<smiles>O=CO[N+]([O-])(O)O[Na]</smiles>

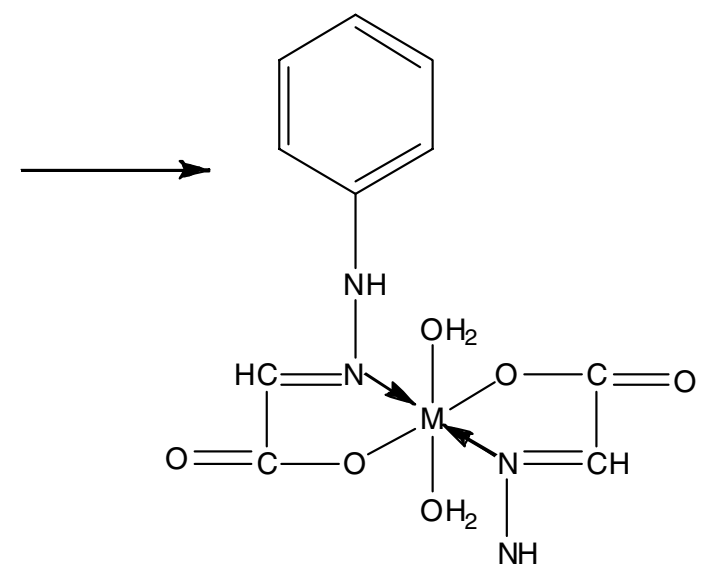

$$
\mathrm{M}=\mathrm{Mn}^{2+}, \mathrm{Co}^{2+}, \mathrm{Ni}^{2+}, \mathrm{Cu}^{2+}, \mathrm{Zn}^{2+} \text { and } \mathrm{Cd}^{2+}
$$




\section{Physical data}

$\mathbf{C}_{16} \mathbf{H}_{18} \mathbf{N}_{4} \mathbf{O}_{6} \mathbf{M n}(\mathbf{1})$ : Yield: $66 \%$. Anal. calcd.: C, 45.17; H, 4.26; N, 15.05; Mn, $12.92 \%$. Found: C, 44.47; H, 4.08; N, 14.95; $\mathrm{Mn}, 11.98 \%$. Molar conductance, $\Lambda_{\mathrm{M}}$ (DMSO): 0.17 $\Omega^{-1} \mathrm{~cm}^{2} \mathrm{~mol}^{-1}$ (non-electrolyte). Magnetic moment $\left(\mu_{\text {eff }}\right): 5.64$ BM. IR (KBr, cm $\left.{ }^{-1}\right): 3299(\mathrm{O}-\mathrm{H}), 3396(\mathrm{~N}-\mathrm{H}), 981(\mathrm{~N}-\mathrm{N}), 1649$ $(\mathrm{C}=\mathrm{N}), 1591\left(\mathrm{COO}^{-}\right)_{\text {asym }}, 1396\left(\mathrm{COO}^{-}\right)_{\mathrm{sym}} .{ }^{1} \mathrm{H} \mathrm{NMR}(400.23 \mathrm{MHz}$, DMSO- $\left.d_{6}, 25^{\circ} \mathrm{C}, \mathrm{TMS}\right): \delta 10.4(\mathrm{~s}, 1 \mathrm{H}, \mathrm{NH}), 7.6(\mathrm{~s}, 1 \mathrm{H}, \mathrm{N}=\mathrm{CH})$, 7.95-7.2 (m, Ar-H), 6.97, 7.1 (2× d, 4 H, OH $\left.\mathrm{OH}_{2}\right) .{ }^{13} \mathrm{CNMR}(400.23$ $\left.\mathrm{MHz}, \mathrm{DMSO}-d_{6}\right): \delta 166.5\left(\mathrm{COO}^{-}\right), 144.5(\mathrm{~N}=\mathrm{CH}), 128.9-137.3$ (Ar-C).

$\mathbf{C}_{16} \mathbf{H}_{18} \mathbf{N}_{4} \mathbf{O}_{6} \mathbf{C o}$ (2): Yield: $81 \%$. Anal. calcd.: C, 44.75; H, 4.22; N, 14.91; Co, $13.73 \%$. Found: C, 43.57; H, 4.13; N, 14.07; Co, $14.18 \%$. Molar conductance, $\Lambda_{\mathrm{M}}$ (DMSO): $0.19 \Omega^{-1} \mathrm{~cm}^{2}$ $\mathrm{mol}^{-1}$ (non-electrolyte). Magnetic moment $\left(\mu_{\text {eff }}\right): 4.86 \mathrm{BM}$. IR $\left(\mathrm{KBr}, \mathrm{cm}^{-1}\right): 3304(\mathrm{O}-\mathrm{H}), 3392(\mathrm{~N}-\mathrm{H}), 986(\mathrm{~N}-\mathrm{N}), 1642(\mathrm{C}=\mathrm{N})$, $1596\left(\mathrm{COO}^{-}\right)_{\text {asym }}, 1398\left(\mathrm{COO}^{-}\right)_{\text {sym. }}{ }^{1} \mathrm{H}$ NMR $(400.23 \mathrm{MHz}$, DMSO$\left.d_{6}, 25^{\circ} \mathrm{C}, \mathrm{TMS}\right): \delta 10.38$ (s, $\left.1 \mathrm{H}, \mathrm{NH}\right), 7.63(\mathrm{~s}, 1 \mathrm{H}, \mathrm{N}=\mathrm{CH}$ ), 7.96-7.26 (m, Ar-H), 6.97, $7.13\left(2 \times \mathrm{d}, 4 \mathrm{H}, \mathrm{OH}_{2}\right) .{ }^{13} \mathrm{C} \mathrm{NMR}$ $\left(400.23 \mathrm{MHz}, \mathrm{DMSO}-d_{6}\right): \delta 166\left(\mathrm{COO}^{-}\right), 144.2(\mathrm{~N}=\mathrm{CH}), 128.6-$ 140.3 (Ar-C).

$\mathbf{C}_{16} \mathbf{H}_{18} \mathbf{N}_{4} \mathbf{O}_{6} \mathbf{N i}(3)$ : Yield: $86 \%$. Anal. calcd.: C, 44.77; H, 4.23; N, 14.92; Ni, $14.68 \%$. Found: C, 44.14; H, 4.13; N, 14.87; Ni, $12.84 \%$. Molar conductance, $\Lambda_{\mathrm{M}}$ (DMSO): 0.12 $\Omega^{-1} \mathrm{~cm}^{2} \mathrm{~mol}^{-1}$ (non-electrolyte). Magnetic moment $\left(\mu_{\text {eff }}\right): 3.1 \mathrm{BM}$. $\operatorname{IR}\left(\mathrm{KBr}, \mathrm{cm}^{-1}\right): 3316(\mathrm{O}-\mathrm{H}), 3397(\mathrm{~N}-\mathrm{H}), 985(\mathrm{~N}-\mathrm{N}), 1645(\mathrm{C}=\mathrm{N})$, $1598\left(\mathrm{COO}^{-}\right)_{\text {aysm }}, 1391\left(\mathrm{COO}^{-}\right)_{\text {sym. }}{ }^{1} \mathrm{HNMR}(400.23 \mathrm{MHz}$, DMSO$\left.d_{6}, 25^{\circ} \mathrm{C}, \mathrm{TMS}\right): \delta 10.3(\mathrm{~s}, 1 \mathrm{H}, \mathrm{NH}), 7.66(\mathrm{~s}, 1 \mathrm{H}, \mathrm{N}=\mathrm{CH}), 6.88$ 7.29 (m, Ar-H), 6.90, $7.14\left(2 \times \mathrm{d}, 4 \mathrm{H}, \mathrm{OH}_{2}\right) .{ }^{13} \mathrm{C} \mathrm{NMR}(400.23$ $\left.\mathrm{MHz}, \mathrm{DMSO}-d_{6}\right): \delta 166.1\left(\mathrm{COO}^{-}\right), 146.1(\mathrm{~N}=\mathrm{CH}), 129.6-140.3$ (Ar-C).

$\mathbf{C}_{16} \mathbf{H}_{18} \mathbf{N}_{4} \mathbf{O}_{6} \mathbf{C u}$ (4): Yield: $72 \%$. Anal. calcd.: C, 44.27; H, 4.18; N, 14.75; Cu, $15.80 \%$. Found: C, 43.98; H, 4.05; N, 13.97; $\mathrm{Cu}, 14.87 \%$. Molar conductance, $\Lambda_{\mathrm{M}}$ (DMSO): 0.15 $\Omega^{-1} \mathrm{~cm}^{2} \mathrm{~mol}^{-1}$ (non-electrolyte). Magnetic moment $\left(\mu_{\mathrm{eff}}\right): 1.84$ BM. IR $\left(\mathrm{KBr}, \mathrm{cm}^{-1}\right)$ : $3278(\mathrm{O}-\mathrm{H}), 3395(\mathrm{~N}-\mathrm{H}), 982(\mathrm{~N}-\mathrm{N})$, $1642(\mathrm{C}=\mathrm{N}), 1596\left(\mathrm{COO}^{-}\right)_{\text {asym }}, 1396\left(\mathrm{COO}^{-}\right)_{\text {sym. }}{ }^{1} \mathrm{H}$ NMR $(400.23$ MHz, DMSO- $\left.d_{6}, 25^{\circ} \mathrm{C}, \mathrm{TMS}\right): \delta 10.56(\mathrm{~s}, 1 \mathrm{H}, \mathrm{NH}), 7.41(\mathrm{~s}$, $1 \mathrm{H}, \mathrm{N}=\mathrm{CH}), 6.98-7.31(\mathrm{~m}, \mathrm{Ar}-\mathrm{H}), 6.86,7.1\left(2 \times \mathrm{d}, 4 \mathrm{H}, \mathrm{OH}_{2}\right)$. ${ }^{13} \mathrm{C}$ NMR (400.23 MHz, DMSO- $\left.d_{6}\right): \delta 165.6\left(\mathrm{COO}^{-}\right), 145.9$ $(\mathrm{N}=\mathrm{CH}), 128.6-139.6$ (Ar-C).

$\mathbf{C}_{16} \mathbf{H}_{18} \mathbf{N}_{4} \mathbf{O}_{6} \mathbf{Z n}$ (5): Yield: $90 \%$. Anal. calcd.: C, 44.08; H, 4.16; N, 14.69; Zn, $15.01 \%$. Found: C, 42.76; H, 4.02; N, 14.07; Zn, $14.36 \%$. Molar conductance, $\Lambda_{\mathrm{M}}$ (DMSO): 0.19 $\Omega^{-1} \mathrm{~cm}^{2} \mathrm{~mol}^{-1}$ (non-electrolyte). Magnetic moment $\left(\mu_{\text {eff }}\right)$ diamagnetic. IR $\left(\mathrm{KBr}, \mathrm{cm}^{-1}\right)$ : $3302(\mathrm{O}-\mathrm{H}), 3396(\mathrm{~N}-\mathrm{H}), 986(\mathrm{~N}-\mathrm{N})$, $1648(\mathrm{C}=\mathrm{N}), 1591\left(\mathrm{COO}^{-}\right)_{\text {asym }}, 1394\left(\mathrm{COO}^{-}\right)_{\text {sym. }}{ }^{1} \mathrm{H}$ NMR $(400.23$ MHz, DMSO- $\left.d_{6}, 25^{\circ} \mathrm{C}, \mathrm{TMS}\right): \delta 10.2(\mathrm{~s}, 1 \mathrm{H}, \mathrm{NH}), 7.62(\mathrm{~s}, 1 \mathrm{H}$, $\mathrm{N}=\mathrm{CH}), 6.85-7.36(\mathrm{~m}, \mathrm{Ar}-\mathrm{H}), 6.89,7.15\left(2 \times \mathrm{d}, 4 \mathrm{H}, \mathrm{OH}_{2}\right)$. ${ }^{13} \mathrm{C}$ NMR (400.23 MHz, DMSO- $\left.d_{6}\right): \delta 164.1\left(\mathrm{COO}^{-}\right), 144.7$ $(\mathrm{N}=\mathrm{CH}), 128.7-139.2(\mathrm{Ar}-\mathrm{C})$.

$\mathbf{C}_{16} \mathbf{H}_{18} \mathbf{N}_{4} \mathbf{O}_{6} \mathbf{C d}$ (6): Yield: $84 \%$. Anal. calcd.: C, 39.79; $\mathrm{H}, 3.75 ; \mathrm{N}, 13.26$; Cd, $23.69 \%$. Found: C, 39.06; H, 3.51; N, 12.18; Cd, $22.65 \%$. Molar conductance, $\Lambda_{\mathrm{M}}$ (DMSO): 0.16 $\Omega^{-1} \mathrm{~cm}^{2} \mathrm{~mol}^{-1}$ (non-electrolyte). Magnetic moment $\left(\mu_{\text {eff }}\right)$ : diamagnetic. IR $\left(\mathrm{KBr}, \mathrm{cm}^{-1}\right): 3352(\mathrm{O}-\mathrm{H}), 3397(\mathrm{~N}-\mathrm{H}), 985(\mathrm{~N}-\mathrm{N})$, $1643(\mathrm{C}=\mathrm{N}), 1599\left(\mathrm{COO}^{-}\right)_{\text {asym }}, 1395\left(\mathrm{COO}^{-}\right)_{\text {sym. }}{ }^{1} \mathrm{H}$ NMR $(400.23$ MHz, DMSO- $\left.d_{6}, 25^{\circ} \mathrm{C}, \mathrm{TMS}\right): \delta 10.3(\mathrm{~s}, 1 \mathrm{H}, \mathrm{NH}), 7.63(\mathrm{~s}, 1 \mathrm{H}$,
$\mathrm{N}=\mathrm{CH}), 6.88-7.27(\mathrm{~m}, \mathrm{Ar}-\mathrm{H}), 6.96,7.1\left(2 \times \mathrm{d}, 4 \mathrm{H}, \mathrm{OH}_{2}\right) .{ }^{13} \mathrm{C}$ $\operatorname{NMR}\left(400.23 \mathrm{MHz}\right.$, DMSO-$\left.d_{6}\right): \delta 166.1\left(\mathrm{COO}^{-}\right), 146.2(\mathrm{~N}=\mathrm{CH})$, 129.1-140.3 (Ar-C).

\section{RESULTS AND DISCUSSION}

Phenyl hydrazoneglyoxylic acid formed in situ by the aqueous condensation between phenyl hydrazine and glyoxylic acid reacts with metal(II) nitrate hydrates to yield phenyl hydrazoneglyoxylato metal(II) complexes. These complexes are stable in air, insoluble in water and soluble in DMSO. The analytical data of the complexes are in accordance with the assigned composition $\mathrm{M}\left(\mathrm{OOCCH}=\mathrm{NNHC}_{6} \mathrm{H}_{5}\right)_{2}\left(\mathrm{H}_{2} \mathrm{O}\right)_{2}$.

The conductivity measurements of 0.01 molar solutions of the complexes in DMSO were found to be around $0.2 \Omega^{-1} \mathrm{~cm}^{2} \mathrm{~mol}^{-1}$ which indicates that these complexes are non-electrolytes [17]. The magnetic moment values reveal their high-spin nature [18].

Electronic absorption spectra: The electronic spectra of cobalt complex show a band at 23,500 $\mathrm{cm}$ which is assigned to ${ }^{4} \mathrm{~T}_{\mathrm{lg}(\mathrm{F})} \rightarrow{ }^{4} \mathrm{~T}_{\mathrm{lg}(\mathrm{P})}$ transition. The nickel complex shows two bands at 14,300 and $20,400 \mathrm{~cm}$ which are assigned to ${ }^{3} \mathrm{~A}_{2 \mathrm{~g}} \rightarrow{ }^{3} \mathrm{~T}_{1 \mathrm{~g}(\mathrm{~F})}$ and ${ }^{3} \mathrm{~A}_{2 \mathrm{~g}} \rightarrow{ }^{3} \mathrm{~T}_{1 \mathrm{~g}(\mathrm{P})}$ transitions respectively. The copper complex shows a band at $16,700 \mathrm{~cm}$ due to the ${ }^{2} \mathrm{E}_{2 \mathrm{~g}} \rightarrow{ }^{2} \mathrm{~T}_{2 \mathrm{~g}}$ transition. All these observations suggest octahedral geometry around the metal ions [19].

Infrared spectra: The infrared spectra of the complexes are almost similar. Sharp bands at 3400,3310 and $3250 \mathrm{~cm}^{-1}$ are assigned to the $\mathrm{N}-\mathrm{H}$ stretching of the ligand and $\mathrm{O}-\mathrm{H}$ stretching of coordinated water molecules. A sharp band observed in $1650-1640 \mathrm{~cm}^{-1}$ is due to the $-\mathrm{HC}=\mathrm{N}-$ stretching of hydrazine moiety. The monodentate nature of carboxylate ion is proposed on the basis of $v_{\text {asy }}$ and $v_{\text {sym }}$ stretching for carboxylate ion seen in the range $1600-1590 \mathrm{~cm}^{-1}$ and $1400-1390 \mathrm{~cm}^{-1}$, respectively. The N-N stretching was observed at $990-980 \mathrm{~cm}^{-1}$ which is higher than the values reported for hydrazine and phenyl hydrazine. This shift could be due to the presence of an electron withdrawing phenyl group in the nitrogen atom $[20,21]$ and coordination of the nitrogen of phenyl hydrazine.

${ }^{1} \mathrm{H}$ NMR and ${ }^{13} \mathrm{C}$ NMR spectra: The ${ }^{1} \mathrm{H}$ NMR of the complexes are similar and show $\mathrm{N}-\mathrm{H}$ proton at $\delta 10.4$ and 11 ppm is probably due to free rotation of the phenyl group and distorted structure. The $\mathrm{C}-\mathrm{H}$ proton of $-\mathrm{N}=\mathrm{CH}-$ is observed at $7.6 \mathrm{ppm}$. Aromatic protons appear in the region 7.26 to 6.95 $\mathrm{ppm}$. The $\mathrm{O}-\mathrm{H}$ protons of water are observed as two doublets in the region 6.79 and $7.1 \mathrm{ppm}$. In ${ }^{13} \mathrm{C}$ NMR spectra, the carboxylate carbon appears at $166.5 \mathrm{ppm}$ and the $-\mathrm{N}=\mathrm{CH}-$ carbon is seen at $144.5 \mathrm{ppm}$. The aromatic carbons are found in the region 140-112 ppm.

Thermal degradation studies: The simultaneous TGDTA traces of the complexes in air and nitrogen atmosphere were recorded to understand the presence and nature of a water molecule (coordinated/non-coordinated) and the ligand pyrolysis patterns. The traces clearly reveal multistep degradation behaviour. The first step is endothermic dehydration as expected takes place in the temperature range $145-220^{\circ} \mathrm{C}$, which could be due to the elimination of coordinated water molecules. This is followed by the ligand pyrolysis yielding the respective metal oxide as the final residue below $600{ }^{\circ} \mathrm{C}$. The TG-DTA traces of the complexes $\mathbf{2}$ and $\mathbf{6}$ are given in Figs. 1 and 2, respectively. 


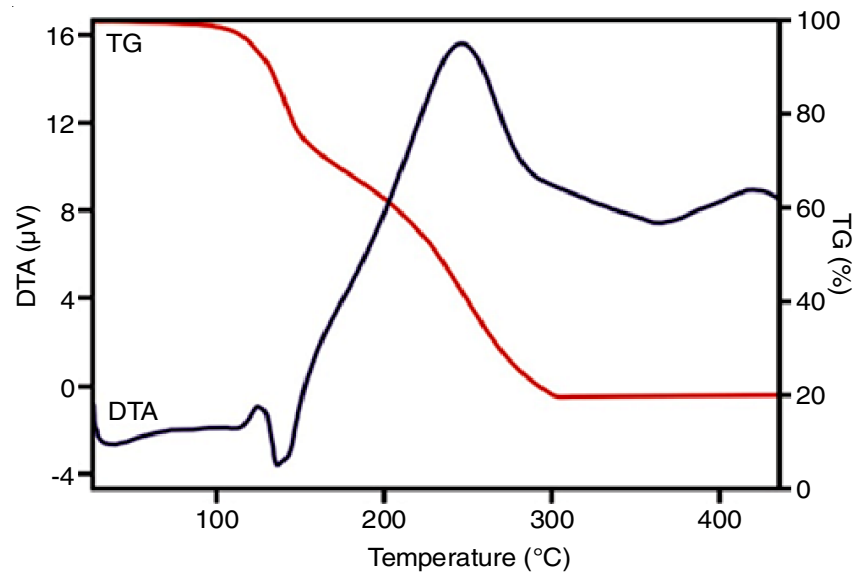

Fig. 1. Simultaneous TG-DTA pattern of complex 2

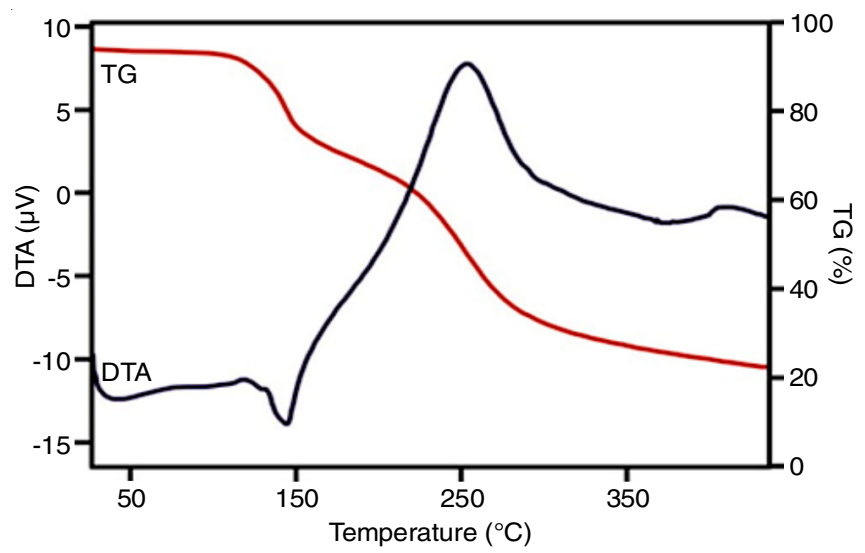

Fig. 2. Simultaneous TG-DTA pattern of complex 6
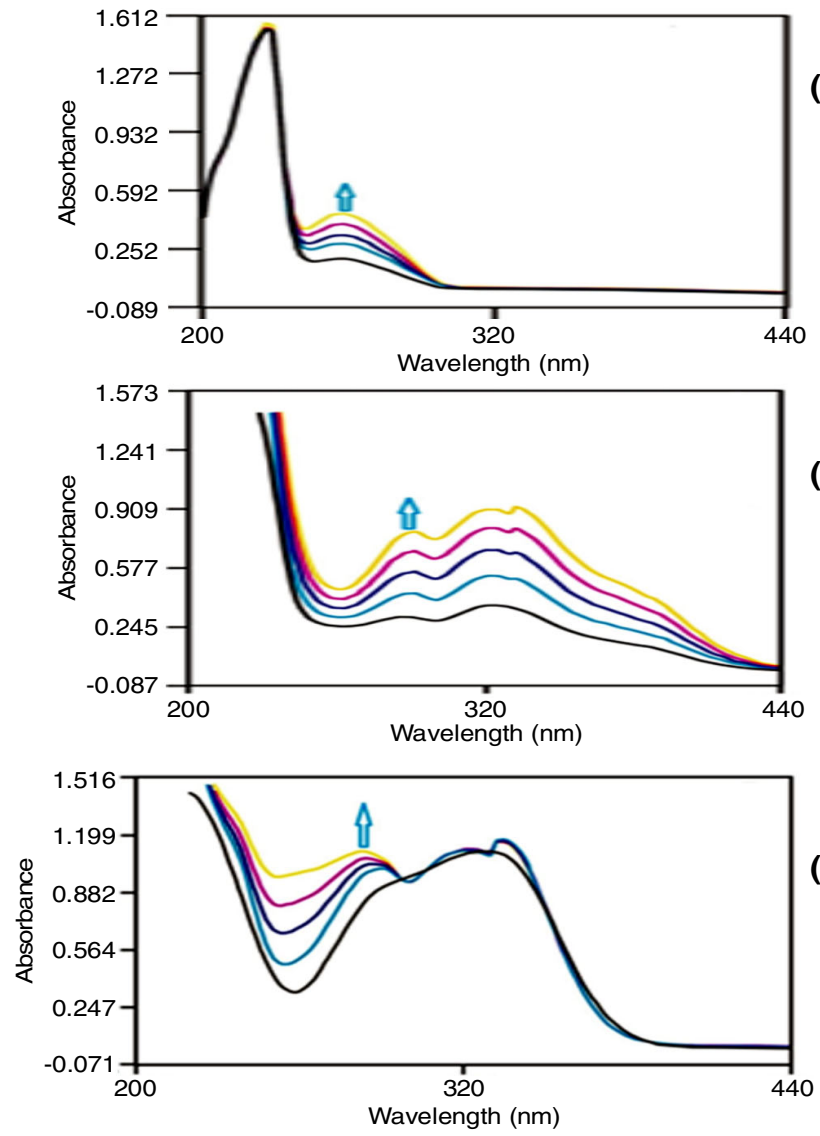

X-ray powder diffraction: The X-ray powder patterns of the complexes are almost super-imposable reflecting their structural similarity. The powder diffraction patterns of the complexes 5 and $\mathbf{6}$ complexes are shown in Figs. 3 and 4, respectively.

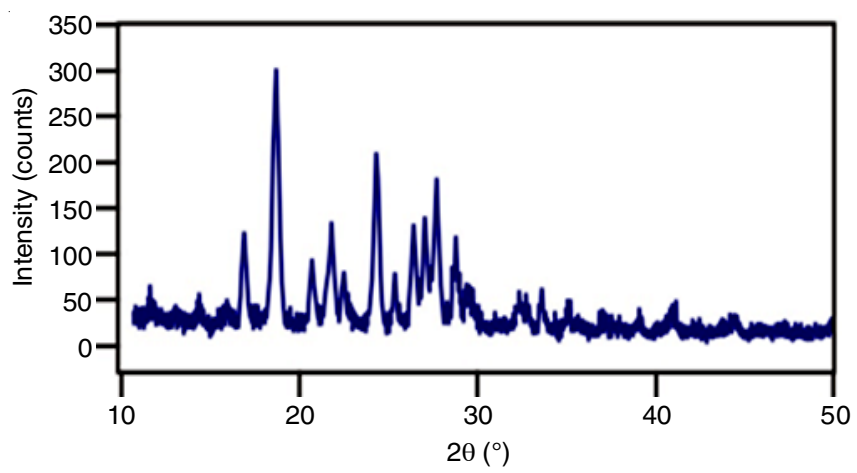

Fig. 3. X-ray powder diffraction pattern of complex 5

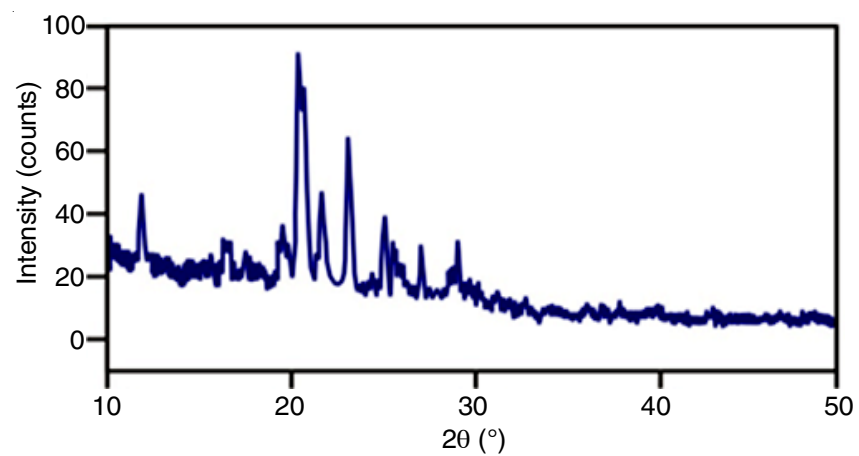

Fig. 4. X-ray powder diffraction pattern of complex 6

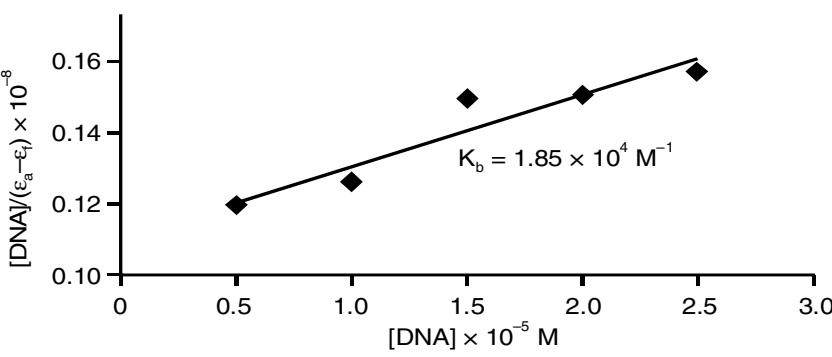

(B)

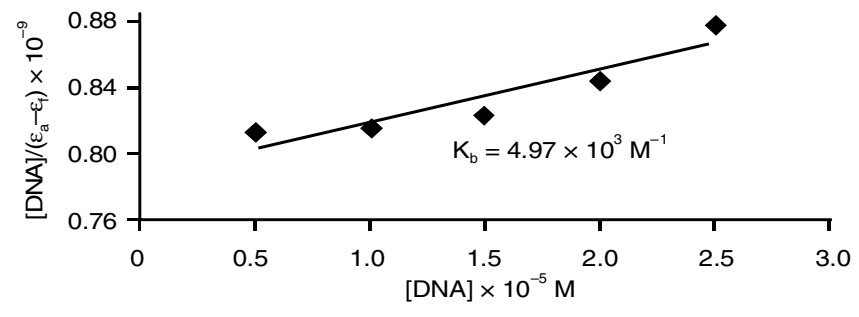

(C)

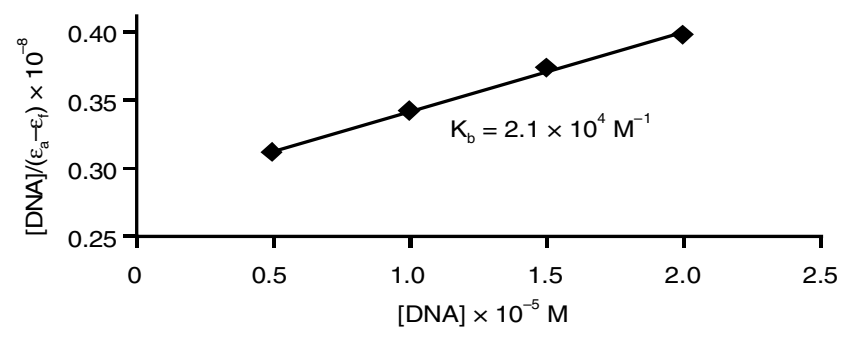

Fig. 5. Absorption spectral traces of the complexes 2 (A), 3 (B) and 5 (C) 


\section{DNA binding studies}

Electronic absorption titration: The electronic absorption spectrum of the complexes $\mathbf{2}, \mathbf{3}$ and $\mathbf{5}$ in DMSO buffer shows intense bands at 267, 286 and $291 \mathrm{~nm}$ respectively. All the complexes show hyperchromic effect with blue shift (about 1 $\mathrm{nm}$ ), which indicates that these complexes bind to DNA by external contact possibly via electrostatic interaction [22,23]. The hyperchromic effect is also due to the electrostatic interaction between positively charged cation and the negatively charged phosphate backbone at the periphery of the double helix-ctDNA [24]. These spectral characteristics indicate that hyperchromism results in the slight change in conformation of DNA due to the cleavage of its secondary structure.

The binding constant $K_{b}$ for complexes 2, 3 and 5 were determined from a plot of [DNA] $/\left(\varepsilon_{\mathrm{a}}-\varepsilon_{\mathrm{f}}\right) v s$. [DNA] and was found to be $1.85 \times 10^{4} \mathrm{M}^{-1}, 4.97 \times 10^{3} \mathrm{M}^{-1}$ and $2.1 \times 10^{4} \mathrm{M}^{-1}$ respectively. The binding constant of the complex $\mathbf{5}$ is greater than that of $\mathbf{2}$ and $\mathbf{3}$. The absorption spectral traces of $\mathbf{2 , 3}$ and 5 at room temperature are shown in Fig. 5A, 5B and 5C respectively. Arrows indicate the change in absorption upon increasing DNA concentration.

Gel electrophoresis: The complexes $\mathbf{2}$ and $\mathbf{5}$ exhibit maximum binding affinity with $c t$ DNA, therefore, the cleavage activity has been evaluated for those complexes. Upon increasing the concentration of the complexes $(25,50,75,100$ $\mu \mathrm{M})$ Form I of $c t$ DNA converted into Form II as shown in Fig. 6. These cleavage efficiencies depend on the concentration of the complexes. The cleavage magnitude of $\mathbf{2}$ and $\mathbf{5}$ were evaluated (Fig. 7) and complex $\mathbf{5}$ is found to exhibit greater cleavage efficiency than complex 2.

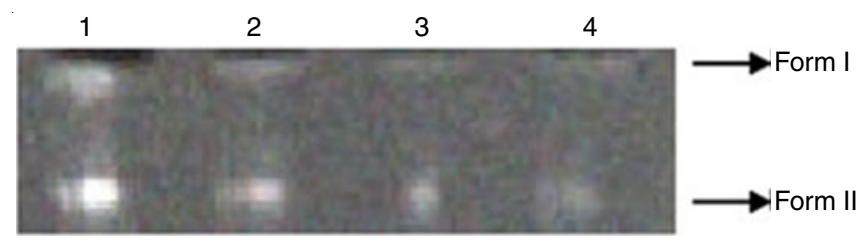

Fig. 6. Cleavage patterns of the agarose gel electrophoresis for $c t$ DNA by Lane 1: $100 \mu \mathrm{M}$ complex 5 + DNA; Lane 2: $75 \mu \mathrm{M}$ complex $\mathbf{5}+$ DNA; Lane 3: $50 \mu \mathrm{M}$ complex 5 + DNA; Lane 4: $25 \mu \mathrm{M}$ complex 5 + DNA

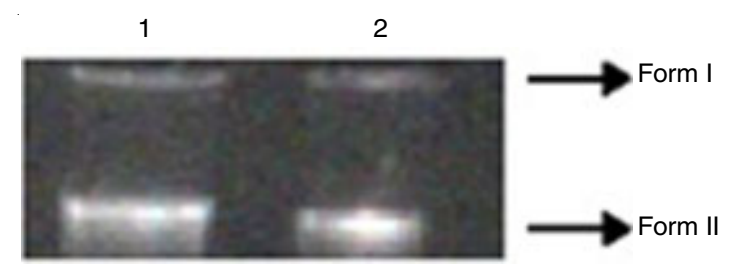

Fig. 7. Cleavage patterns of the agarose gel electrophoresis for $c t$ DNA by Lane 1: complex $5(100 \mu \mathrm{M})+$ DNA; Lane 2: complex $2(100 \mu \mathrm{M})$ + DNA

\section{ACKNOWLEDGEMENTS}

One of the authors (R. Pradeep) expresses his gratitude to University Grants Commission, New Delhi for the award of RGNFD fellowship (Ref. No. F/2014-15/RGNF-2014-15DOBC-TAM-84300).

\section{REFERENCES}

1. R. Selvakumar, T. Premkumar, V. Manivannan, K. Saravanan and S. Govindrajan, South Afr. J. Chem., 67, 52 (2014).

2. T. Premkumar, R. Selvakumar, N.P. Rath and S. Govindrajan, South Afr. J. Chem., 67, 85 (2014).

3. S. Yasodhai, T. Sivakumar and S. Govindarajan, Thermochim. Acta, 338, 57 (1999);

https://doi.org/10.1016/S0040-6031(99)00192-6.

4. K. Kuppusamy, B.N. Sivasankar and S. Govindarajan, Thermochim. Acta, 259, 251 (1995);

https://doi.org/10.1016/0040-6031(95)02257-3.

5. S. Yasodhai and S. Govindrajan, J. Therm. Anal. Calorim., 62, 737 (2000); https://doi.org/10.1023/A:1026781610640.;

6. R. Manimekalai, C.R. Sinduja and K. Kalpanadevi, Int. J. Inorg. Chem., Article ID 624374 (2012);

https://doi.org/10.1155/2012/624374.

7. C. Sonia and B.N. Sivasankar, Synth. React. Inorg. Met.-Org. Nano-Met. Chem., 44, 1119 (2014);

https://doi.org/10.1080/15533174.2013.799195.

8. R. Ragul, L. Vikram and B.N. Sivasankar, Synth. React. Inorg. Met.-Org. Nano-Met. Chem., 45, 1069 (2015); https://doi.org/10.1080/15533174.2013.862654.

9. B.N. Sivasankar and S. Govindarajan, J. Therm. Anal. Calorim., 48, 1401 (1997); https://doi.org/10.1007/BF01983451.;

10. B.N. Sivasankar and S. Govindrajan, Z. Naturforsch., 49b, 950 (1994).

11. P. Ravindranathan and K.C. Patil, Thermochim. Acta, 71, 53 (1983); https://doi.org/10.1016/0040-6031(83)80354-2.

12. D. Nicholls, M. Rowley and R. Swindells, J. Chem. Soc. A, 950 (1966); https://doi.org/10.1039/J19660000950.

13. A.I. Vogels, A Text Book of Quantitative Inorganic Analysis, Longmans, London, edn 3 (1962).

14. J. Marmur, J. Mol. Biol., 3, 208 (1961); https://doi.org/10.1016/S0022-2836(61)80047-8.

15. C.V. Kumar and E.H. Asuncion, J. Am. Chem. Soc., 115, 8547 (1993); https://doi.org/10.1021/ja00072a004.

16. Reddy, K.S. Rao and B. Satyanarayana, Tetrahedron Lett., 47, 7311 (2006); https://doi.org/10.1016/j.tetlet.2006.08.033.

17. W.J. Geary, Coord. Chem. Rev., 7, 81 (1971); https://doi.org/10.1016/S0010-8545(00)80009-0.

18. B.N. Figgis and J. Lewis, The Magnetochemistry of Complex Compounds in Morden Coordination Chemistry, Wilkins Interscience, New York (1996).

19. A.P.B. Lever, Inorganic Electronic Spectroscopy, Elsevier, Amsterdam, edn 2 (1984).

20. A. Braibanti, F. Dallavalle, M.A. Pellinghelli and E. Leporati, Inorg. Chem., 7, 1430 (1968); https://doi.org/10.1021/ic50065a034.

21. K. Nakamoto, Infrared and Raman spectra of Inorganic and Coordination Compounds, Wiley Interscience, New York, edn 3 (1978).

22. F. Arjmand and S. Parveen, RSC Adv., 2, 6354 (2012); https://doi.org/10.1039/c2ra20660a.

23. M.S. Surendra Babu, K.H. Reddy and P.G. Krishna, Polyhedron, 26, 572 (2007); https://doi.org/10.1016/j.poly.2006.08.026.

24. N. Shahabadi, S. Kashanian, M. Mahdavi and N. Sourinejad, Bioinorg. Chem. Appl., Article ID 525794 (2011); https://doi.org/10.1155/2011/525794. 